\title{
Analisis Besaran Komponen Imbangan Air pada Lahan Irigasi Kelingi Tugumulyo Kabupaten Musi Rawas Provinsi Sumatera Selatan
}

\author{
'Okma Yendri, 2Dinar DA Putranto, ${ }^{3}$ Sarino \\ Prodi Teknik Sipil Fakultas Teknik Universitas Musi Rawas \\ ${ }^{2} 3$ Dosen Program Magister Teknik Sipil Universitas Sriwijaya \\ E-mail: okmayendri@gmail.com
}

\begin{abstract}
Absrak. Penggunaan Air di suatu Daerah Irigasi menjadi hal yang sangat penting agar sumber daya air yang ada dapat dialokasikan ke semua daerah irigasi secara efisien dan efektif. Pemberian air irigasi dan hujan akan mempengaruhi imbangan air di lahan. Bila diketahui ada kelebihan ketersediaan air terhadap kebutuhan air irigasi, maka dapat dilakukan penghematan dan dimanfaatkan lagi untuk berbagai kepentingan lain. Sistem imbangan air irigasi di lahan meliputi hujan, suplai air, kebutuhan air untuk tanaman dan kelebihan air perlu di kelolah dengan baik dengan model simulasi untuk mengetahui besaran parameter-parameter dalam imbangan air dilahan irigasi dengan menerapkan secara koninyu, terjadwal dan terkontorol. Berdasarkan hasil simulasi menunjukkan kebutuhan air irigasi dengan cara pemberian secara terjadwal merupakan yang paling sedikit yaitu $523.31 \mathrm{~mm}$ per musim tanam, diikuti pemberian air secara kontinyu $587.36 \mathrm{~mm}$ per musim tanam, kemudian pemberian air secara terkontrol sebesar $618.71 \mathrm{~mm}$ per musim tanam.
\end{abstract}

Kata kunci: penggunaan air irigasi, sistem imbangan air, hasil simulasi

\section{PENDAHULUAN}

Komponen ketersediaan air meliputi hujan dan pemberian air irigasi yang berpengaruh pada tinggi genangan di sawah, aliran permukaan dan aliran bawah permukaan, Untuk kegiatan pengembangan sumber daya air di daerah irigasi selalu berhubungan dengan persoalan ketersediaan air. Pemberian air irigasi dan hujan akan mempengaruhi imbangan air di lahan, sehingga penggunaan air di suatu Daerah Irigasi (DI) menjadi hal yang sangat penting, agar sumberdaya air yang ada dapat dialokasikan ke semua daerah irigasi secara efisien dan efektif. Apabila diketahui ada kelebihan ketersediaan air terhadap kebutuhan air irigasi yang ada, diharapkan dapat dilakukan penghematan air agar dapat dimanfaatkan kembali untuk berbagai kepentingan lainnya (Awliya Tribuana, 2002).

Peningkatan efisiensi pemakaian air irigasi pada sawah dapat dilakukan dengan pemberiana air yang tepat. Secara umum dapat dikelompokkan menjadi tiga bagian yaitu: (1) pemberian air kontinyu, (2) pemberian air secara terjadwal, (3) pemberian air secara terkontrol. (Awliya Tribuana, 2002).

\section{Penelitian Terdahulu}

Penelitian yang dilakukan oleh Suyitno (1999) menyatakan bahwa kebutuhan air daerah Kabupaten Dati II Gunungkidul pada tahun 2019 sebesar 703,72 1t/dt (22.192.535,12 m3 / tahun), dan kebutuhan air untuk penduduk sebesar $0,37 \%$ per tahun. Terdapat beberapa daerah yang minus air, yaitu Kecamatan Panggang, Ponjong, Patuk, Nglipar, Ngawen, Semin, dan Gedangsari. Untuk kecamatan selain yang tersebut di atas surplus air. Awliya Tribuana, 2002 meneliti tentang" Imbangan Air Pada Lahan Irigasi " dengan hasil simulasi menunjukkan bahwa cara pemberian terjadwal yang paling sedikit kebutuhan air irigasinya yaitu sebesar $369,50 \mathrm{~mm}$ diikuti pemberian air secara terkontrol 435,28 $\mathrm{mm}$ selanjutnya pemberian air secara kontinyu sebesar $475 \mathrm{~mm}$.

Konsep Imbangan Air di Lahan Irigasi. 


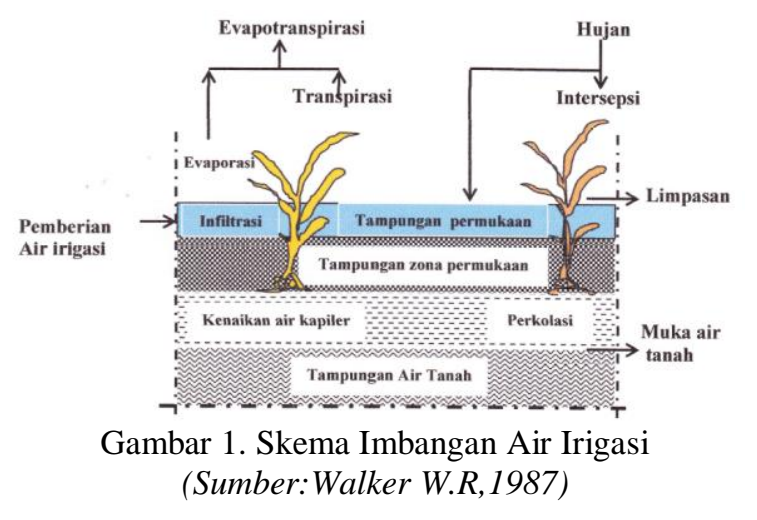

Prinsip kontinuitas digunakan dalam imbangan air irigasi adalah inflow (I) dikurang Outflow (O) merupakan perubahan tampungan $(\Delta S)$ pada beberapa kondisis batas sistem yang dinyatakan dalam persamaan 2.1 berikut:

$\mathrm{I}-\mathrm{O}=\Delta \mathrm{S}$ 1

Apabila persamaan 1 dibuat lebih rinci, akan didapat suatu persamaan imbangan air di areal usaha tanaman (Sudjarwadi, 1990) sebagai berikut:

$(\mathrm{HJ}+\mathrm{AI})-(\mathrm{AL}+\mathrm{P}+\mathrm{E}+\mathrm{T})=\mathrm{PADT}+\mathrm{PATT}$.

Dimana; HJ = Hujan (mm); AI=Air Irigasi (mm); AL= Air Limpasan (mm); E = Evaporasi $(\mathrm{mm}) ; \mathrm{T}=$ Transpirasi $(\mathrm{mm})$; $\mathrm{P}=$ Perkolasi $(\mathrm{mm})$; PADT=Perubahan air dalam tanah; PATT=Perubahan air dalam tubuh tanaman. Persamaan 2 menunjukkan bahwa ( HJ + AI ) adalah hujan ditambah air irigasi. Dalam hal ini konstribusi kenaikan kapiler dari tanah dan limpasan dari daerah lebih tinggi dianggap nol (diabaikan).

\section{Unsur-unsur yang Berpengaruh pada Kebutuhan Air Irigasi Hujan Efektif Dasar}

Hujan efektif dasar adalah bagian hujan yang jatuh yang dapat dipergunakan oleh tanaman di sawah atau hujan efektif dasar adalah hujan dikurangi kehilangan air akibat intersepsi. Besaran hujan efektif dasar dihitung berdasarkan rumus yang dinyatakan sebagai berikut :

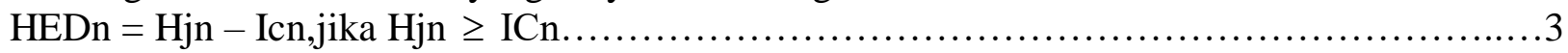

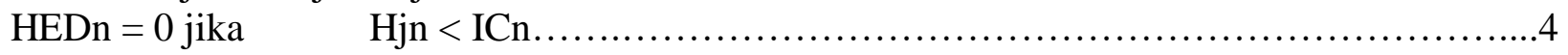

Dimana:HEDn=Hujan efektif dasar hari ke n; ICn= Itersepsi hari ke n; Hjn= Hujan hari ke n.

Curah hujan yang langsung jatuh di petak sawah bila jumlahnya melebihi kapasitas intersepsi akan menyebabkan perubahan tinggi genangan di sawah. Sebalikanya jika tidak ada hujan maka genangan dapat turun sampai di bawah genangan minimum, untuk itu dilakukan pengisian dengan pemberian air irigasi, pada kondisi batas yang dinyatakan dalam persamaan 5 .

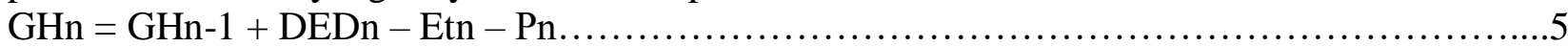

GHN > GEMAK $\quad$ :maka GHn = GEMAK

GEMIN $<$ GHn $<$ GEMAK :maka GHn = GHn

GHn $<$ GEMIN :maka

$\mathrm{GHn}=\mathrm{Ghn}-1+\mathrm{HEDn}-\mathrm{Etn}-\mathrm{Pn}+\mathrm{PAI}$

$\mathrm{PAI}=\mathrm{GENOR}-\mathrm{GHn}$

Dimana : GHn = Tinggi genangan hari ke n; GHn-1=Tinggi genangan hari ke n-1; HEDn=Hujan efektif dasar hari ke n; GEMAK=Genagan maksimum; GENOR=Genangan normal; Etn= Evapotranspirasi hari ke $\mathrm{n} ; \mathrm{Pn}=$ Perkolasi hari ke $\mathrm{n}$; PAI=Pemberian air irigasi $(\mathrm{mm})$.

\section{Hujan Efektif}

Hitungan simulasi nilai hujan efektif dengan memperhitungkan pemberian air di petak sawah ada tiga batasan tinggi genangan yang diterapkan, yaitu tinggi genangan maksimum (GEMAK), tinggi genangan normal (GENOR), dan tinggi genangan minimum (GEMIN). Dengan tiga batasan tinggi genangan air di petak sawah tersebut diperoleh tiga kondisi untuk menentukan besar nilai hujan efektif pada hari ke $n$ sebagai berikut : 


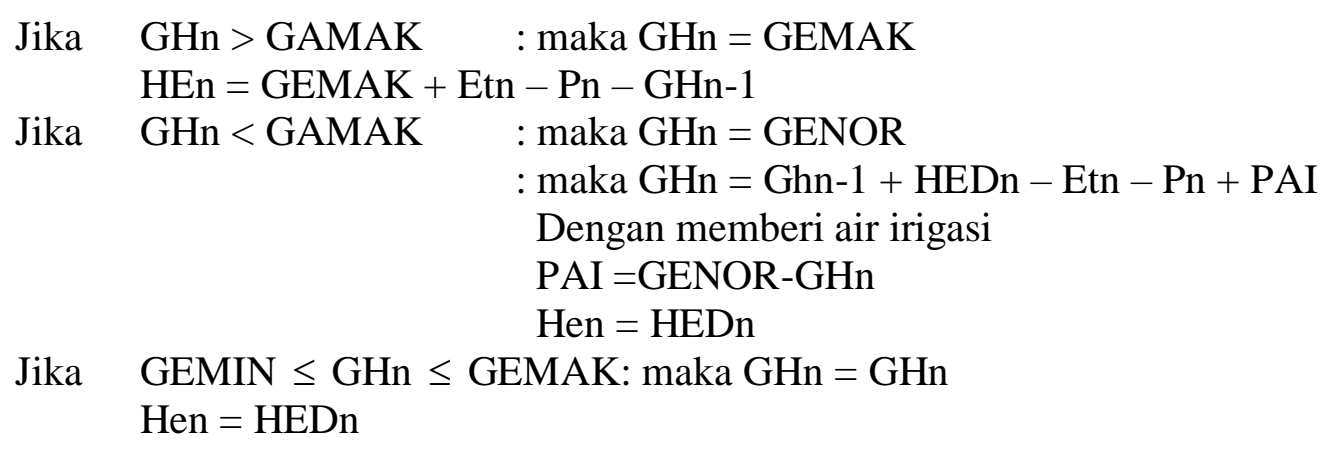

\section{Intersepsi}

Besarnya intersepsi dapat dihitung dengan pendekatan rumus Hossain (1969), dalam Sudjarwadi (1990). Nilai kapasitas intersepsi untuk tanaman padi tidak sama dengan nilai intersepsi pada tanaman palawija. Harga intersepsi untuk tanaman padi dapat dinyatakan dengan persamaan:

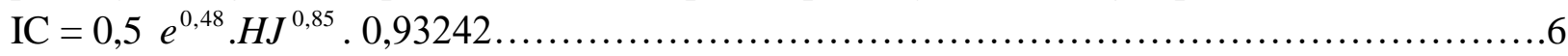

Sedangkan untuk tanaman sesuai dengan vegetasi penutup lahan, maka besarnya intersepsi diambil setengah dari nilai intersepsi pada tanaman padi (Utomo.M,1990), sehingga menjadi persamaan :

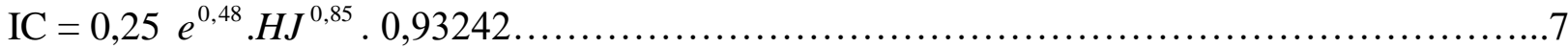
dimana : IC=Intersepsi; $\mathrm{HJ}=$ Hujan

\section{Evapotranspirasi}

Nilai evapotranspirasi dapat didekati berdasarkan besaran evapotranspirasi potensial (ETo) kemudian dikalikan dengan koefisien tanaman (Kt), (Dorenbos dan Pruitt, 1977), dalam (Sudjarwadi 1990).

$\mathrm{Et}=\mathrm{Kt}$ x ETo.................................................................. 8

Dimana $: E t=$ Evapotranspirasi $(\mathrm{mm} / \mathrm{hari}) ; \mathrm{Kt}=$ Koefosien $\quad$ tanaman; $\quad \mathrm{ETo}=$ Evapotranspirasi potensial (mm/hari).

Metode yang digunakan sebagai dasar untuk menghitung evapotranspirasi potensial. Bentuk rumus Penman yang telah dimodifikasi oleh FAO adalah sebagai berikut:

$\mathrm{ETo}=\mathrm{c}[W \cdot R n+(1-W) x f(u) \cdot(e d-e a)]$.

Dimana:

ETo =Evapotranspirasi potensial $(\mathrm{mm} / \mathrm{hari})$;

$\mathrm{C} \quad=$ faktor pendekatan untuk persamaan Penman;

$\mathrm{W} \quad=$ Faktor yang tergantung pada temperature rerata dan ketinggian Tempat;

$\mathrm{Rn}=$ Radiasi netto dalam evaporasi ekuivalen $(\mathrm{mm} / \mathrm{hari})=\mathrm{Rns}-\mathrm{Rn} 1$;

Rns =Radiasi netto gelombang pendek $(\mathrm{mm} / \mathrm{hari})=$ Ra.B. $(1-\mathrm{a})$;

$\mathrm{Ra}=$ Radiasi matahari maksimum ( $\mathrm{mm} / \mathrm{hari})$;

$\mathrm{B}=0,25+0,50 . \mathrm{n} / \mathrm{N}$

$\mathrm{n} / \mathrm{N} \quad=$ Faktorkonversi dari Ra ke R;

a $\quad=$ Angka pematulan $=0,25$;

Rn1 =radiasi netto gelombang panjang $(\mathrm{mm} / \mathrm{hari})=\mathrm{f}(\mathrm{T}) . \mathrm{f}(\mathrm{ed}) . \mathrm{F}(\mathrm{n} / \mathrm{N})$;

$\mathrm{F}(\mathrm{T}) \quad=$ Efek temperature pada gelombang panjang $=117,4 \mathrm{X} 10^{-e} \cdot T^{4}=0,34-0,044 . \mathrm{ed}^{0,5}$;

ed $\quad=$ Tekanan uap jenuh pada suhu udara rata-rata (mbar) $=$ ea $\times \mathrm{RH}$;

ea = Tekanan uap jenuh pada suhu rata-rata (mbar); $\mathrm{RH}=$ Kelembaban relatif (\%);

$\mathrm{F}(\mathrm{n} / \mathrm{N})=$ Efek keawanan pada gelombang panjang $=0,10+0,99 \cdot \mathrm{n} / \mathrm{N}$;

$\mathrm{F}(\mathrm{u}) \quad=$ Efek kecepatan angin pada gelombang panjang=0,27 $\left(1+U_{2} / 100\right)$;

$U_{2} \quad=$ Kecepatan angin pada ketinggian tempat $2 \mathrm{~m}$. 


\section{Koefisien Tanaman}

Pemilihan nilai Koefisen Tanaman didasarkan pada watak tanaman, waktu tanam, usia tanam dan kondisi iklim pada umumnya kriteria perencanaan irigasi (1986) telah memberikan koefisien tanaman bulalan untuk jenis padi dan palawija sebagai-berikut :

Tabel 1. Koefisien Tanaman Padi

\begin{tabular}{cc}
\hline Bulan & Varietas Unggul \\
\hline 0,5 & 1.20 \\
1,0 & 1,27 \\
1,5 & 1,33 \\
2,0 & 1,30 \\
2,5 & 1,30 \\
3,0 & 0,00 \\
\hline Sumber : Standar Perencanaan Irigasi KP.0, 1986
\end{tabular}

\section{Perkolasi}

Perkolasi adalah proses aliran air dalam tanah secara vertikal akibat gaya grafitasi. Perkolasi akan terjadi apabila kapasitas lapang telah terlampaui. Beberapa faktor yang berpengaruh dalam proses perkolasi diantaranya adalah sifat fisik, kedalaman muka air tanah, lengas tanah, kapasitas lapng tanah, dan kapasitas tanah.

\begin{tabular}{lc}
$\begin{array}{c}\text { Table 2. Hubungan Jenis Tanah dengan Laju Perkolasi } \\
\text { Jenis Tanah }\end{array}$ & $\begin{array}{c}\text { Laju Perkolasi } \\
\text { (mm/hr) }\end{array}$ \\
\hline Geluh berpasir (Standy Loam) & $3-6$ \\
Geluh (Loam) & $2-3$ \\
Geluh berliat (clay loam) & $1-2$ \\
\hline Sumber : Standar Perencanaan Irigasi KP.01,1986
\end{tabular}

\section{Kebutuhan Air Untuk Tanaman}

Kebutuhan air untuk tanaman padi secara metematis dapat dinyatakan sebagai berikut:

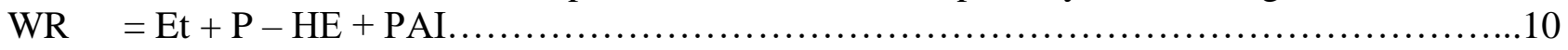

Dimana:

WR = Kebutuhan air untuk tanaman padi $(\mathrm{mm})$

$\mathrm{E} \mathrm{t} \quad=$ Evapotranspirasi $(\mathrm{mm})$

$\mathrm{P} \quad=$ Perkolasi $(\mathrm{mm})$

HE $\quad=$ Hujan efektif $(\mathrm{mm})$

PAI $=$ Pemberian Air Irigasi $(\mathrm{mm})$.

\section{Cara Pemberian Air Irigasi}

Pemberian Air Secara Kontinyu

Pemberian air secara kontinyu, dilakukan dengan mengalirkan air terus-menerus ke dalam patak sawah dengan jumlah air yang diberikan besarnya tetap pada tiap-tiap pereode dalam satu musim tanam. Besar debit pemberian air ditentukan dengan memperhatikan hujan yang jatuh dalam petak dan tidak terjadi genangan minimum. Status tinggi genengan di lahan pada hari ke $n$ untuk pemberian air secara kontinyu dirumuskan dengan persamaan:

$\mathrm{GHn}=\mathrm{GHn}-1+\mathrm{HEDn}+\mathrm{PAI}-\mathrm{Etn}-\mathrm{Pn}$.

GHn $>$ GHn-1 : maka Ghn=GEMAK

GEMAK $<$ GHn $<$ GEMAK $:$ maka GHn=GHn

GHn $<$ GEMIN : maka GHn=GEMIN

Dimana: GHn=Tinggi genangan hari ke n; GHn-1=Tinggi genangan hari ke n-1; HEDn=Hujan efektif dasar hari ke n; Etn = Evapotranspirasi hari ke n; Pn=Perkolasi hari ke n; GEMAK= Tinggi genangan maksimum; GEMIN=Tinggi genangan minimum; PAI = Pemberian Air Irigasi.

Secara skematis batasan genangan air di sawah untuk pemberian air secara kontinyu dapat dilihat pada Gambar 2. 


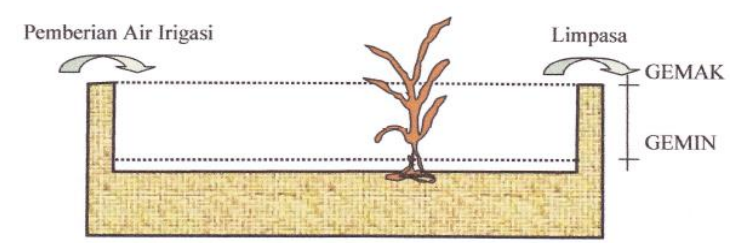

Gambar 2. Batasan tinggi genangan air di sawah pemberian air secara Kontinyu.

\section{Pemberian Air Secara Terjadwal}

Pemberian air secara terjadwal, dilakukan dengan memberikan air dalam waktu tertentu selama musim tanam (secara periodik). Besar air irigasi yang diberikan adalah sampai genangan air normal. Status tinggi genangan di lahan pada hari ke $\mathrm{n}$ untuk pemberian secara terjadwal dirumuskan dengan persamaan:

GHn=Ghn-1+HEDn-Etn-Pn....................................................... 12

GHn $>$ GEMAK $:$ maka GHn=GEMAK

GEMIN $<$ GHn $<$ GEMAK $\quad$ : maka GHn $=$ Ghn

GHn<GEMIN : maka GHn-GEMIN

$\mathrm{N}=$ pereode pemberian air $\quad$ : maka

GHn=Ghn-1_HEDn-Etn-Pn+PAI

PAI=GENOR-GHn.

Dimana: GHn =Tinggi genangan hari ke n; GHn-1=Tinggi genangan hari ke n-1; HEDn=Hujan efektif dasar hari ke n; Etn=Evapotranspirasi hari ke n; Pn=Perkolasi hari ke n; GEMAK=Tinggi genangan maksimum; GENOR=Tinggi genangan normal; PAI=Pemberian air irigasi $(\mathrm{mm})$.

Secara skematis batasan genangan air di sawah untu pemberian air secara terjadwal dilihat pada Gambar 3

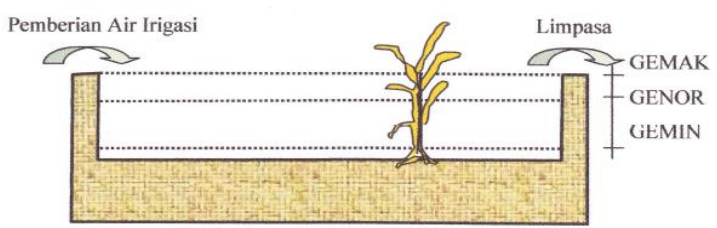

Gambar 3. Batasan tinggi genangan air di sawah pemberian air secara Terjadwal.

\section{Pemberian Air Secara Terkontrol}

Pemberian air secara terkontrol berdasarkan perubahan tampungan dilakukan dengan memberikan air jika kondisi genangan mencapai ketinggian tertentu. Pada prosedur perhitungan model tinggi genangan dimana air segera ditambahkan disebut GEMIN, besar GEMIN dapat dilakukan sampai kedalaman 0. Air irigasi yang diberikan sampai ketinggian GENOR.

$\mathrm{GHn}=\mathrm{GHn}-1+\mathrm{HEDn}-\mathrm{Etn}-\mathrm{Pn}$

GHn $>$ GEMAK : maka GHn=GEMAK

GEMIN $>$ GEMAK $\quad$ : maka GHn=GHn

GHn<GEMIN : maka

$\mathrm{GHn}=\mathrm{GHn}-1+\mathrm{HEDn}-\mathrm{Etn}-\mathrm{Pn}+\mathrm{PAI}$

PAI=GENOR-GHn.

Dimana: GHn=Tinggi genangan hari ke n; GHn-1=Tinggi genangan hari ke n-1; HEDn=Hujan efektif dasar hari ke n; Etn=Evapotranspirasi hari ke n; Pn=Perkolasi hari ke n; GEMAK=Tinggi genangan maksimum; GENOR=Tinggi genagan normal; GEMIN=Tinggi genangan maksimum; PAI=Pemberian air irigasi (mm).

Secara skematis batasan genangan air di sawah untuk pemberian air secara terkontrol dapat dilihat pada Gambar 4 


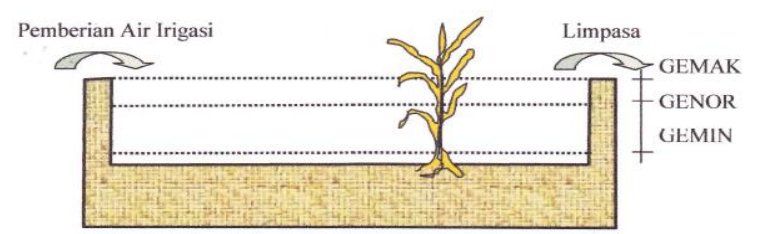

Gambar 4. Batasan tinggi genangan air di sawah pemberian air secara Terkontrol

\section{Dasar Hitungan Imbangan Air}

Tinjauan pengalihragaman curah hujan dan pemberian air irigasi ke aliran drainase dapat didekati dengan prinsip imbangan air sederhana seperti pada gambar:

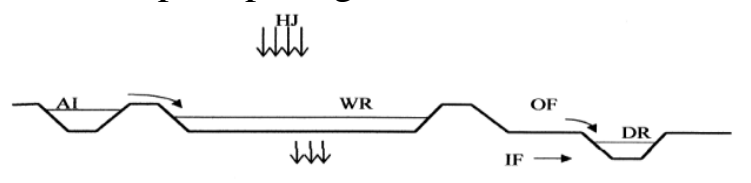

Gambar 5. Imbangan Air di Lahan

Pada persamaan 2.14 air yang diterima adalah air hujan dan pemberian air irigasi. Air yang hilang adalah aliran permukaan, perkolasi, evaporasi, dan transpirasi. Air tersimpan adalah simpanan intersepsi, perubahan kandungan air tanah, simpanan permukaan.

\section{Bentuk Aliran Air}

Air keluar dari suatu areal tertentu melalui beberapa bentuk antara lain yaitu:

a. Aliran permukaan (overland flow), adalah air yang mengalir di atas permukaan tanah

b. Aliran bawah tanah (groun water), adalah air yang masuk dan terperkolasi jauh kedalam tanah menjadi air bawah tanah. Air ini mengalir didalam tanah dengan lambat masuk kedalam sungai.

Persamaanya dapat ditulis sebagai berikut:

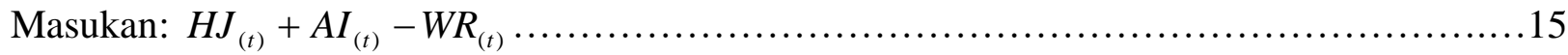

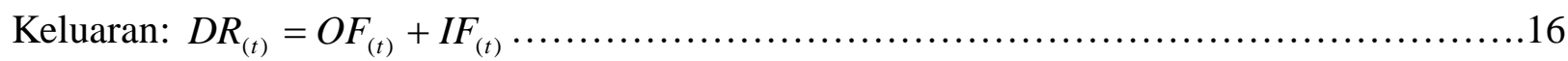

Dimana: $D R_{t}=$ Debit keluaran (drainase) pada saat $\mathrm{t}(1 / \mathrm{dt}) ; A I_{t}=$ Debit irigasi dari intake pada saat $\mathrm{t}(\mathrm{l} / \mathrm{dt})$; $H J_{t}=$ Debit karena hujan pada saat $\mathrm{t}(1 / \mathrm{dt}) ; W R_{t}=$ Kebuthan air irigasi pada saat $\mathrm{t}(\mathrm{l} / \mathrm{dt}) ; O F_{t}=$ Debit karena "overland flow" pada sat $\mathrm{t}(\mathrm{l} / \mathrm{dt}) ; I F_{t}=$ Debit karena "inter flow" pada sat $\mathrm{t}(\mathrm{l} / \mathrm{dt})$

\section{Infiltrasi}

Infiltrasi terjadi pada saat awal mempunyai laju infiltrasi yang tinggi, akan tetapi makin lama makin rendah sehingga mencapai laju infiltrasi tetap. Harto (1939) mengemukakan rumusan infiltrasi:

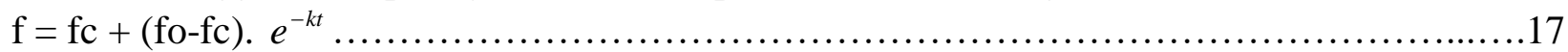

Dimana: $\mathrm{f}=$ Kapasitas infiltrasi atau laju maksimum infiltrasi pada suatu saat $(\mathrm{cm} / \mathrm{jam}) \mathrm{fc}=$ Kapasitas infiltrasi pada saat infiltrasi telah konstan; fo = Kapasitas infitrasi pada pemulaan hujan; $\mathrm{k}=$ Suatu konstanta bagi suatu tanah; = Waktu; e= 2,71828.

\section{Lengas Tanah}

Persamaan imbangan lengas tanah dinyatakan sebagai berikut:

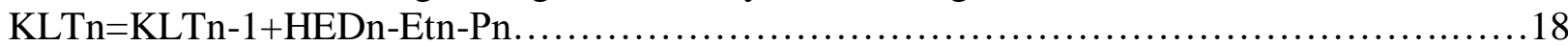

Dimana :KLTn=Kadar lengas tanah hari ke n; KLTn-1=Kadar lengas tanah hari ke n-1; HEDn= Hujan efektif hari ke n; Etn=Evapotranspirasi hari ke n; Pn=Perkolasi hari ke n

Ada tiga batasan dalam penentuan lengas tanah berdasarkan tinggi genangan di lahan

$\mathrm{GHn}=\mathrm{Ghn}-1+\mathrm{HEDn}-\mathrm{Etn}-\mathrm{Pn}$.

GHn $>$ GEMAK maka GHn=GEMAK

$\mathrm{LTn}=\mathrm{KAJ}$

GHn $>$ GEMIN maka GHn $=\mathrm{GHn}$ 


\section{GHn<GEMIN maka GHn=GEMIN \\ LTn=LTn-1+HEDn-Etn-Pn+PAI}

Dimana: GHN =Tinggi genangan hari ke n; GHn-1=Tinggi genangan hari ke n-1; HEDn=Hujan efektif dasar hari ke n; Etn=Evapotranspirasi hari ke n; Pn=Perkolasi hari ke n; GEMAK=Tinggi genangan maksimum; GEMIN=Tinggi genangan minimum; PAI= Pemberian air irigasi $(\mathrm{mm})$; KAJ $=$ Kapasitas jenuh $(\mathrm{mm}) ; \mathrm{LTn}=$ Lengas tanah hari ke n; LTn-1=Lengas tanah hari ke n-1.

\section{Kapasitas Jenuh}

Kapasitas jenuh adalah jumlah air yang diperlukan untuk mengisi seluruh ruang pori antara butirbutir tanah. Nilai kapasitas jenuh didekati berdasarkan rumus berukut Sudjarwadi 1990 dalam Awliya T,2002;

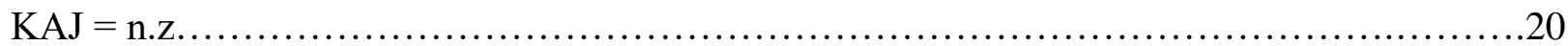

Dimana :KAJ=Kapasitas jenuh $(\mathrm{mm}) ; \mathrm{n}=$ Porositas tanah $(\%) ; \mathrm{z}=$ Kedalaman daerah perakaran $(\mathrm{mm})$

\section{Kapasitas Lapang}

Penentuan nilai kapasitas lapang berdasarka kapasitas jenuh diusulkan oleh Sudjarwadi 1990 dalam Awliya T,2002 dengan persamaan :

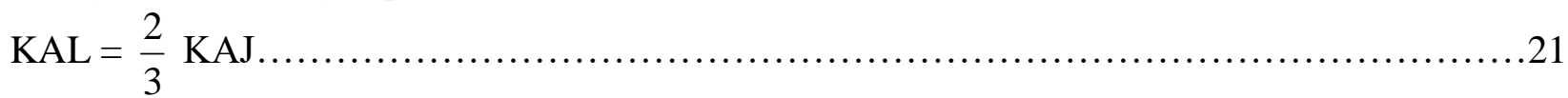

Dimana : KAL= Kapasitas lapang $(\mathrm{mm}) ; \mathrm{KAJ}=\mathrm{Kapasitas}$ jenuh $(\mathrm{mm})$.

\section{METODE PENELITIAN \\ Pendekatan Masalah dan Asumsi}

a. Ketersediaan air hujan pada daerah irigasi dipengaruhi oleh ruang dan waktu, maka untuk mengetahui perilakunya dari waktu ke waktu didekati dengan cara hitungan simulasi hujan efektif harian selama musim tanam; b.Kebutuhan air tanaman ditinjau berdasarkan tinggi genangan maksimum $200 \mathrm{~mm}$ ( besarnya sama dengan tinggi pematang sawah), tinggi genangan normal $150 \mathrm{~mm}$ ( tinggi genangan yang disetkan di sawah dengan pemberian air irigasi pada saat genagngan yang terjadi lebih kecil dari genagan minimum ) dan tinggi genangan minimum $50 \mathrm{~mm}$ ( tinggi genangan yang masih diijinkan ). (Sumber: Awliya T, 2002); c.Pemberian tinggi genangan awal $150 \mathrm{~mm}$. (Sumber: Awliya T, 2002); d.Bila curah hujan yang jatuh langsung di petak sawah jumlahnya melebihi kapasitas intersepsi akan menyebabkan perubahan tinggi genangan sawah, sebaliknya jika tidak ada hujan maka genangan akan turun sampai dibawah genangan minimum, untuk itu dilakukan pengisisn dengan pemberian air irigasi; d.Tanah pada daerah penelitian adalah seragam; e.Kehilangan air akibat rembesan kesamping diabaikan. f. Besaran evapotranspirasi harian konstan mengikuti evaporasi rerata bulanan; g.Bersarnya perkolasi konstan; h.Padi yang ditanam adalah varitas unggul dengan usia pertumbuhan 90 hari; i.Faktor yang mempengaruhi terjadinya debit drainase hanya ditentukan oleh curah hujan dan pemberian air irigasi, yang selanjutnya dapat dimanfaatkan kembali.

\section{Data yang diperlukan}

a. Data Klimatologi. Data klimatologi diperlukan untuk menentukan evapotranspirasi potensial. Data klimatologi diperlukan yang terdiri dari data suhu, kelembaban udara, kecepatan angin, dan lamanya penyinaran matahari dari stasiun Klimatologi terdekat yaitu di dusun Tegal Rejo Kecamatan Tugumulyo Kabupaten Musi Rawas dari tahun 2004 sampai tahun 2010.

b. Data curah hujan harian. Data curah hujan harian tersedia berupa data hujan antara tahun 2000 sampai tahun 2012 Data hujan harian ini merupakan hasil rekaman stasiun hujan di dusun Tegalrejo Kecamatan Tugumulyo Kabupaten Musi Rawas.

c. Lahan. Data lahan meliputi luas lahan, perkolasi, koefisien tanaman, dapat dijelaskan sebagai berikut: a. Luas lahan sawah adalah 5.268 ha di Kecamatan Tugumulyo Kabupaten Musi Rawas. (Sumber: Kecamatan Tugumulyo Dalam Angka.2004); b. Perkolasi dipakai sesuai dengan Kriteria Perencanaan 
Irigasi (1996); c. Koefisien tanaman yang dipakai sesuai dengan Kriteria Perencanaan Irigasi (1986); d. Data Pola Tanam.

\section{Pengujian Data}

Tahap pengujian umumnya disebut dengan penyaringan (screening) data, dengan maksud untuk memeriksa dan memilih atau mengelompokkan data yang bertujuan untuk memperoleh data hidrologi yang cukup handal untuk analisis sehingga kesimpulan yang akan diperoleh cukup baik. Pengertian pengujian; a.Data tidak homogen ada penyimpangan data dari sifat statistiknya yang disebabkan oleh faktor alam dan manusia; b.Data tidak konsisten adalah penyimpangan data karena kesalahan acak dan kesalahan sistematisnya. Uji Stasioner Data Curah Hujan adalah; a. Uji kestabilan nilai rata-rata; b. Uji kesetabilan varian.

\section{Menyusun Model Simulasi \\ Model Imbangan Air}

Beberapa anggapan yang digunakan dalam simulasi model imbangan air di sawah sebagai berikut: a. Berlaku prinsip imbangan air di sawah; b. Masukan model yang tidak diperoleh dari pengukuran ditentukan berdasarkan persamaan empirik maupun asumsi yang biasa berlaku pada praktek irigasi di Indonesia; c. Tinggi genangan awal pada saat bibit dipindahkan ke petak sawah sama dengan genangan saat pengolahan tanah; d. Hitungan suplai air dari sistem irigasi ke drainase merupakan pengembangan model imbangan air dilahan; e. Keterbatasan data tentang ground water recharge maka penyelesaian model didekati dengan menggunakan model imbangan air, dengan modifikasi input berupa tinggi genangan.

\section{Suplai Air}

Hujan yang jatuh pada lahan irigasi dan pemberian air merupakan suplai air, untuk mengetahui jumlah debit drinase akibat penghematan dari penggunaan air untuk usaha pertanian dari suplai, maka pada studi ini dilakukan dengan mencoba beberapa alternatif pemberian air irigasi.

Hitungan debit drainase mengikuti konsep imbangan air ( water balance), seperti Gambar 6
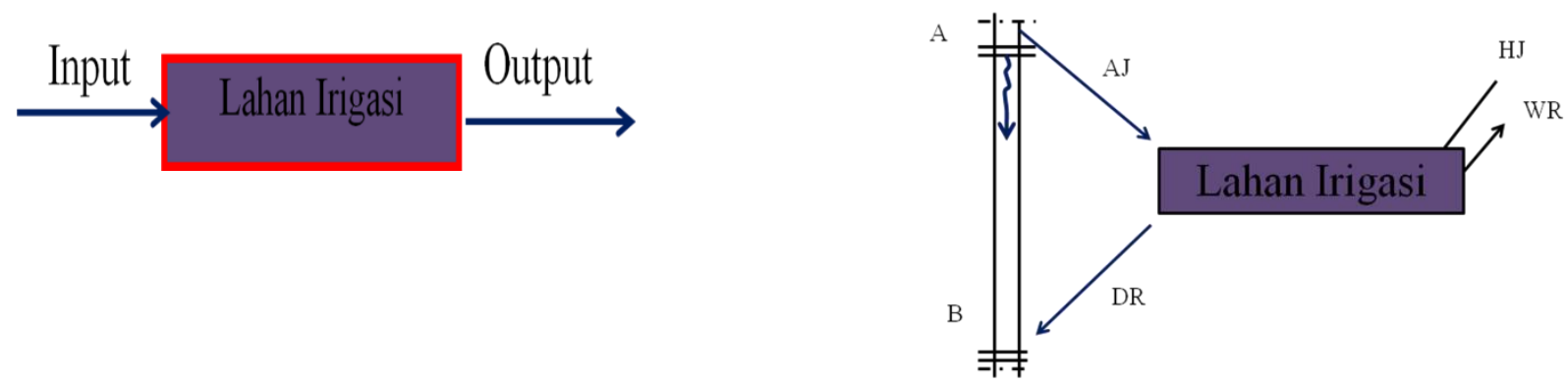

Gambar 6. Skema Model Imbangan Air Sederhana.

\section{Perumusan Model}

Sebagai data masukan (input) model adalah berupa debit pemberian air irigasi (AI), hujan jatuh dilahan (HJ), dan kebutuhan air untuk irigasi (WR). Sedangkan keluaran (output) berupa debit drinase (DR) yang dapat dimanfaatkan kembali oleh lahan irigasi di sebelah hilir.

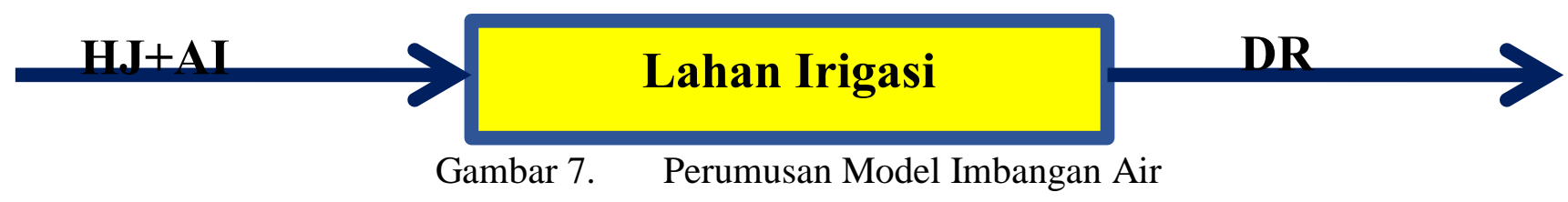




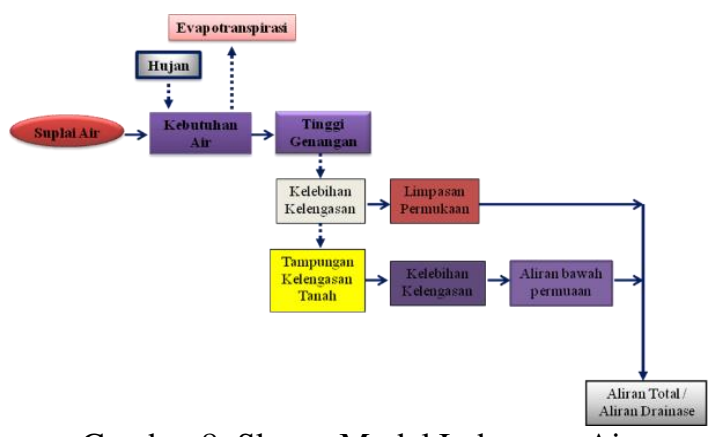

Gambar 8. Skema Model Imbangan Air

\section{HASIL DAN PEMBAHASAN}

\section{Pemberian Air Secara Kontinyu}

Hasil pemberian air secara kontinyu dilakukan dengan cara memberikan air sebesar $5 \mathrm{~mm}$ secara terus menerus selama satu musim tanam. Pada tabel 3. kebutuhan air hanya selama pertumbuhan tanaman sedangkan kebutuhan air untuk pengelolahan termasuk efisiensi belum diperhitungkan.

Tabel 3.Imbangan Air di Lahan Irigasi Kelingi Tugumulyo Pemberian Secara Kontinyu.

\begin{tabular}{ccccc}
\hline \multirow{2}{*}{ Musim Tanam } & \multicolumn{2}{c}{ Masukan } & Kebutuhan & \multicolumn{2}{c}{ Keluaran } \\
Air $(\mathbf{m m})$ & Pujan $(\mathbf{m m})$ & PAI (mm) & 587.36 & 566.77 \\
DT 1 & 566.00 & 475.00 & 697.73 & 676.69 \\
MT 2 & 305.00 & 480.00 & 639.27 & 628.34 \\
MT 3 & 502.50 & 480.00 & & (mm) \\
\hline
\end{tabular}

\section{Pemberian Air Secara Terjadwal}

Sistem Pemberian air secara terjawal dilakukan dengan cara member air pereode selama 5 harian selama satu musim tanam. Suplai air irigasi dilakukan hingga mencapai genangan normal sebesar $150 \mathrm{~mm}$. Pada Tabel 4. kebutuhan air hanya selama pertumbuhan tanaman sedangkan kebutuhan air untuk pengelolahan termasuk efisiensi sebelumnya diperhitungkan.

Tabel 4.Imbangan Air di Lahan Irigasi Kelingi Tugumulyo Pemberian Secara Terjadwal

\begin{tabular}{|c|c|c|c|c|}
\hline \multirow{2}{*}{ Musim Tanam } & \multicolumn{2}{|c|}{ Masukan } & \multirow{2}{*}{$\begin{array}{c}\text { Kebutuhan } \\
\text { Air }(\mathbf{m m})\end{array}$} & \multirow{2}{*}{$\begin{array}{c}\text { Keluaran } \\
\text { Drainase }(\mathbf{m m})\end{array}$} \\
\hline & Hujan (mm) & PAI (mm) & & \\
\hline MT 1 & 566.00 & 359.00 & 523.31 & 555.39 \\
\hline MT 2 & 305.00 & 359.00 & 597.85 & 586.81 \\
\hline MT 3 & 502.50 & 407.00 & 596.48 & 607.35 \\
\hline
\end{tabular}

\section{Pemberian Air Secara Terkontrol}

Pada pemberian air secara terkontrol saat tinggi genagan $50 \mathrm{~mm}$ dilakukan dengan pemberian air irigasi apa bila tinggi genangan di lahan turun sampai tinggi genangan minimum $50 \mathrm{~mm}$. Tabel 5. kebutuhan air hanya selama pertumbuhan tanaman sedangkan kebutuhan air untuk pengelolaan termasuk efisiensi belum diperhitungkan.

Table 5. Imbangan Air di Lahan Irigasi Kelingi Tugumulyo dengan Pemberian Secara Terkontrol.

\begin{tabular}{|c|c|c|c|c|}
\hline \multirow{2}{*}{ Musim Tanam } & \multicolumn{2}{|c|}{ Masukan } & \multirow{2}{*}{$\begin{array}{c}\text { Kebutuhan } \\
\text { Air (mm) }\end{array}$} & \multirow{2}{*}{$\begin{array}{c}\text { Keluaran } \\
\text { Drainase }(\mathbf{m m})\end{array}$} \\
\hline & Hujan (mm) & PAI (mm) & & \\
\hline MT 1 & 566.00 & 447.84 & 563.97 & 557.65 \\
\hline MT 2 & 305.00 & 368.91 & 638.78 & 627.21 \\
\hline MT 3 & 502.50 & 447.86 & 818.71 & 612.38 \\
\hline
\end{tabular}

\section{Pembahasan \\ Imbangan Air}

Pada imbangan air di lahan irigasi, sebagai data masukan ( input ) adalah hujan yang jatuh dilahan, pemberian air irigasi dan kebutuhan air tanaman sedangkan keluaran ( output ) berupa debit drinase yang dapat dimanfaatkan kembali oleh daerah irigasi hilir table 6. 
Okma Yendri et al, Analisis Besaran Komponen Imbangan Air pada Lahan Irigasi Kelingi Tugumulyo Kabupaten Musi Rawas Provinsi Sumatera Selatan

Tabel 6. Imbangan Air di Lahan Irigasi Kelingi Tugumulyo Musim Tanam Satu (MT1).

\begin{tabular}{|c|c|c|c|c|}
\hline \multirow{2}{*}{ Cara Pemberian Air } & \multicolumn{2}{|c|}{ Masukan } & \multirow{2}{*}{$\begin{array}{c}\text { Keb. } \\
\text { Air }(\mathbf{m m})\end{array}$} & \multirow{2}{*}{$\begin{array}{c}\text { Keluaran } \\
\text { Drainase }(\mathbf{m m})\end{array}$} \\
\hline & Hujan (mm) & PAI (mm) & & \\
\hline Kontinyu & 566.00 & 475.00 & 587.36 & 566.77 \\
\hline Terjadwal & 566.00 & 359.00 & 523.31 & 555.39 \\
\hline Terkontrol & 566.00 & 447.86 & 618.71 & 612.38 \\
\hline
\end{tabular}

\section{Kebutuhan Air}

Dalam pemberian air secara kontinyu diberikan setinggi $5 \mathrm{~mm}$ perhari Dengan tinggi genangan maksimum (GAMAK) ditentukan sebesar $200 \mathrm{~mm}$. Pada hari pertama pemberian air irigasi diberikan sebesar $150 \mathrm{~mm}$ sehingga mendapatkan tinggi genangan sebesar $150 \mathrm{~mm}$, hal ini disesuaikan dengan kondisi daerah irigasi Kelingi Tugumulyo, dimana saat pemindahan bibit ke sawah tinggi genangan yang ada sebesar $150 \mathrm{~mm}$, selanjutnya untuk hari kedua dan seterusnya pemberian air dibesikan sebesar $5 \mathrm{~mm}$. Tinggi genangan yang terjadi di pengaruhi oleh hujan, pemeberian air dan kebutuhan air untuk pertumbuhan tanaman.

Hari ke tiga (3) pemberian air secara kontinyu $5 \mathrm{~mm}$, pengaruh hujan efektif sebesar $8.527 \mathrm{~mm}$ sudah dapat dipertimbangkan dengan memberi air irigasi sebesar $5 \mathrm{~mm}$ lebih rendah dari kebutuhan air untuk tanaman sebesar $1.79 \mathrm{~mm}$ dengan kekurangan sebesar $3.21 \mathrm{~mm}$ dicukupi oleh hujan efektif, hujan efektif dapat menaikan tinggi genangan.

Saat pemeberian air secara kontinyu, pemberian air $5 \mathrm{~mm}$ secara terus menerus, yang terjadi tinggi genangan tetap terjaga sampai menjelang panen. Apabila tinggi genangan tetap terjadi menjelang panen maka akan menggangu, karena itu pada hari ke enampuluh tujuh (67) pemberian air $5 \mathrm{~mm}$ tidak diberikan lagi dengan kondisi tinggi genangan $144.39 \mathrm{~mm}$. diperhitungkan kebutuhan air akan mencukupi kebutuhan untuk pertumbuhan tanaman hingga menjelang panen dan tinggi genengan tetap terjaga walaupun mengalami penurunan hingga genangan nol pada hari ke 85 saat menjelang panen. Kebutuhan air untuk pemeberian secara kontinyu $5 \mathrm{~mm}$ selama Sembilan puluh (90) hari sebesar $475.00 \mathrm{~mm}$.

Sistem pemberian air secara terjadwal dilakukan dengan cara memberikan air sampai ketinggian genangan normal yang ditentukan sebesar $150 \mathrm{~mm}$ kemudian dihentikan dan diberikan setiap lima hari adalah : a. Hari pertama pemberian air irigasi diberikan sebesar $150 \mathrm{~mm}$ sehingga mendapat tinggi genangan sebesar $150 \mathrm{~mm}$, karena sesuai dengan daerah irigasi Kelingi Tugumulyo dimana saat pemindahan bibit ke sawah tinggi genangan yang ada sebesar $150 \mathrm{~mm}$, selanjutnya untuk hari kedua hingga hari keempat tidak dilakukan pemberian air, sehingga tinggi genangan akan turun sesuai dengan kebutuhan air untuk kebutuhan tanaman. Tinggi genangan yang terjadi dipengaruhi oleh hujan, pereode pemberian air dan kebutuhan air untuk pertumbuhan tanaman; b. Hari kelima tinggi genangan turun mencapai ketinggian $141.59 \mathrm{~mm}$, maka dilakukan pengisian sebesar $12.00 \mathrm{~mm}$ sehingga tinggi genangan di sawah akan naik mencapai tinggi genagan normal sebesar $149.95 \mathrm{~mm}$; c.Pada hari kesepuluh tinggi genangan turun mencapai ketinggian $124.68 \mathrm{~mm}$, maka dilakukan pengisian sebesar $20.00 \mathrm{~mm}$ sehingga tinggi genangan di sawah akan naik mencapai tinggi genagan normal sebesar $149.00 \mathrm{~mm}$; d. Pada hari ke enam puluh tidak dilakukan pengisian air sebab tinggi genangan sebesar $144.39 \mathrm{~mm}$ cukup memenuhi kebutuhan untuk pertumbuhan tanaman hingga panen.Kemudian pada hari ke delapan puluh lima (85) tinggi genangan akan nol. Kebutuhan air untuk pemberian air secara terjadwal 5 harian selama sembilan puluh hari sebesar $523.31 \mathrm{~mm}$; e.Sistem pemeberian air secara terkontrol dilakukan apabila tinggi genangan di sawah turun, maka pengisian air irigasi mwncapai genagan normal ditentukan sebesar $150 \mathrm{~mm}$, tinggi genangan maksimum ditentukan sebesar $200 \mathrm{~mm}$; f. Pada hari ke delapan belas tinggi genangan sebesar $42.78 \mathrm{~mm}$, dilakukan pengisian air sebesar $101.90 \mathrm{~mm}$, tinggi genangan pada hari ke sembilan belas naik manjedi $144.68 \mathrm{~mm}$; f.Pada hari ke tiga puluh delapan tinggi genangan sebesar $79.23 \mathrm{~mm}$, dilakukan pengisian air sebesar $72.19 \mathrm{~mm}$, tinggi genangan pada hari ke tiga puluh sembilan naik manjedi $144.73 \mathrm{~mm}$; g.Pada hari ke lima puluh lima tinggi genangan sebesar $20.96 \mathrm{~mm}$, dilakukan pengisian air sebesar $123.77 \mathrm{~mm}$, tinggi genangan pada hari ke limapuluh enam naik manjedi $144.73 \mathrm{~mm}$. dengan memperhitungkan tinggi genangan hari ke limapuluh lima ini akan cukup memenuhi kebutuhan air untuk pertumbuhan tanaman hingga panen dan tinggi genangan akan nol pada saat umur 85 hari sebagai upaya persiapan panen. Kebutuhan air untuk pemberian air secara terkontrol selama sembilan puluh hari sebesar $618.71 \mathrm{~mm}$; h.Hasil keluaran model simulasi 
diketahui bahwa cara pemberian air secara terkontrol adalah yang paling banyak membutuhkan air irigasi yaitu $618.71 \mathrm{~mm}$ selanjutnya pemberian air secara kontinyu sebesar $587.36 \mathrm{~mm}$ dan pemberian air secara terjadwal sebesar $523.31 \mathrm{~mm}$.

\section{Aliran Permukaan dan Aliran Bawah Permukaan}

Hasil keluaran model berupa aliran permukaan dan aliran bawah permukaan sehingga didapat debit drainase untuk pemberian air secara kontinyu sebagaimana terlihat dari tabel Tabel 3. Untuk Musim Tanam Satu (MT1), Musim Tanam Dua (MT2), Musim Tanam Tiga (MT3) menunjukkan bahwa overland flow tidak terjadi, hal ini disebabkan tinggi genangan yang terjadi dilahan tidak melebihi tinggi genangan maksimum sebesar $200 \mathrm{~mm}$, sedangkan untuk aliran bawah permukaan atau perkolasi Musim Tanam Satu (MT1), Musim Tanam Dua (MT2), Musim Tanam Tiga (MT3) diambil 4 mm dari Tabel 2.

\section{Pemberian Air dan tinggi Genangan}

Gambaran pemberian air secara kontinyu dan tinggi genangan, dengan model imbangan air di sawah dapat dilihat pada gambar 9 .
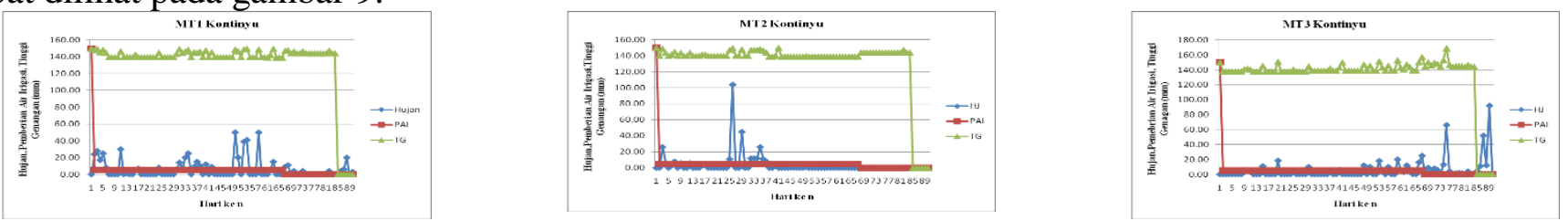

Gambar 9. Hujan, Pemberian air irigasi dan tinggi genangan untuk pemberian air secara kontinyu musim tanam 1, musim tanam 2 , musim tanam 3 .

Gambaran pemberian air secara terjadwal dan tinggi genganan, dengan model imbangan air di sawah dapat dilihat pada gambar 10 .
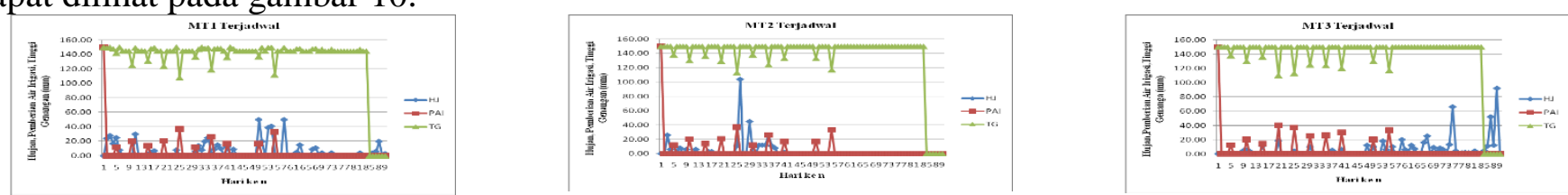

Gambar 10. Hujan, Pemberian air irigasi dan tinggi genangan untuk pemberian air secara terjadwal musim tanam 1, musim tanam 2, musim tanam 3.

Gambaran pemberian air secara terkontrol dan tinggi genganan, dengan model imbangan air di sawah dapat dilihat pada gambar 11.
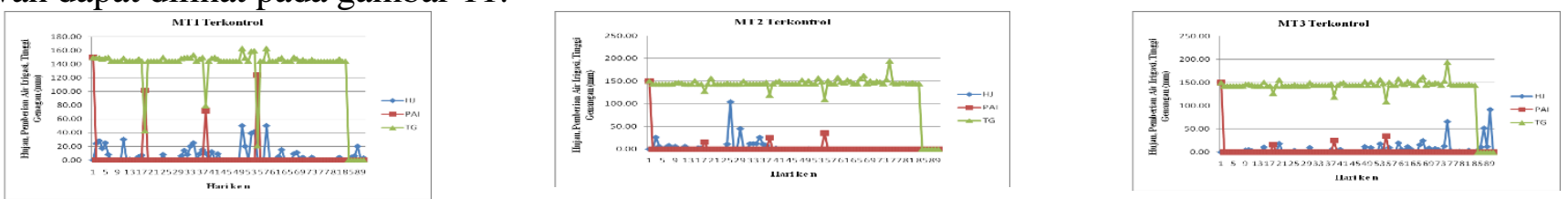

Gambar 11. Hujan, Pemberian air irigasi dan tinggi genangan untuk pemberian air secara terkontrol musim tanam 1, musim tanam 2 , musim tanam 3 .

\section{SIMPULAN}

1. Komponen-komponen besaran imbangan air pada lahan irigasi Kelingi Tugumulyo untuk pemberian air secara kontinyu pada musim tanam satu (MT1) adalah masukan berupa hujan sebesar $566.00 \mathrm{~mm}$, pemberian air irigasi sebesar $475.00 \mathrm{~mm}$ dan kebutuhan air sebesar $587.36 \mathrm{~mm}$ sedangkan keluaran debit drainase sebesar $566.77 \mathrm{~mm}$. Komponen-komponen besaran imbangan air pada lahan irigasi Kelingi Tugumulyo untuk pemberian air secara terjadwal pada musim tanam satu (MT1) adalah masukan berupa hujan sebesar $566.00 \mathrm{~mm}$, pemberian air irigasi sebesar $359.00 \mathrm{~mm}$ dan kebutuhan air sebesar $523.31 \mathrm{~mm}$ sedangkan keluaran debit drainase sebesar $555.39 \mathrm{~mm}$. Komponen-komponen besaran imbangan air pada lahan irigasi Kelingi Tugumulyo untuk pemberian air secara terkontrol pada musim tanam satu (MT1) adalah masukan berupa hujan sebesar $566.00 \mathrm{~mm}$, pemberian air irigasi sebesar $447.86 \mathrm{~mm}$ dan kebutuhan air sebesar $618.71 \mathrm{~mm}$ sedangkan keluaran debit drainase sebesar $612.38 \mathrm{~mm}$. 
2. Pemberian air yang dilakukan terdapat perbedaan diantaranya cara kontinyu, terjadwal, terkontrol akan mempengaruhi pada besaran suplai air, sehingga berpengaruh pada tinggi genangan yang terjadi pada masing-masing cara pemberian air selanjutnya akan berpengaruh pada kelengasan tanah yang mengakibatkan pada besaran drainase.

3. Pada lokasi penelitian, Di Lahan Irigasi Kelingi Tugumulyo air yang disuplai secara kontinyu $5 \mathrm{~mm}$, kebutuhan air adalah $475.00 \mathrm{~mm}$, apabila memakai cara terjadwal maka akan menghemat sebesar 359.00 $\mathrm{mm}$, apabila memakai cara terkontrol sebesar $447.86 \mathrm{~mm}$.

4. Kebutuhan air irigasi dipengaruhi oleh hujan efektif, tinggi genangan di sawah, perkolasi dan cara pemberian air yang digunakan.

5. Dari hasil simulasi menunjukkan bahwa cara pemberian air terjadwal yang paling sedikit membutuhkan air irigasi sebesar $359.00 \mathrm{~mm}$ diikuti pemberian air secara terkontrol $447.86 \mathrm{~mm}$, kemudian pemberian air secara kontinyu sebesar $475.00 \mathrm{~mm}$.

\section{Saran}

1. Dari simulasi yang dilakukan perlu penelitian lebih lanjut untuk efisiensi air irigasi di Irigasi Kelingi Tugumulyo.

2. Hasil dari keluaran imbangan air yang dilakukan di lahan irigasi air sisa atau kelebihan air dapat dipergunakan pada bagian hilir di Irigasi Kelingi Tugumulyo.

\section{DAFTAR PUSTAKA}

Awliya Tribhuwana, 2002, “Analisis imbangan air pada lahan irigasi” Tesis, PP Universitas Diponegoro Semarang.

Lily Montarcih Limantara, 2010, Hidrologi Prakstis.Penerbit Lubuk Agung Bandung.

Nugroho Hadisusanto,2011,Aplikasi Hidrologi, Penerbit Jogja Medautama Yogyakarta.

Suryono Sosrodarsono, Ir. Kensaku Takeda,Hidrologi Untuk Pengairan, 2006, Penerbit Pradia Paramita, Jakarta.

Chay Asdak, Hirologi dan Pengelolaan daerah Aliran Sungai, 2007, Penerbir Gajah Mada University Press. Tukimin, 2002, "Simulasi pemberian air irigasi dengan kajian hujan efektif "Tesis, PPS Universitas Diponegoro Semarang.

Anonim, 1986, Standar Perencanaan Irigasi Direktorat Jendral Pengairan, Departemen Pekerjaan Umum. Pasca Sarjana UNSRI, 2001 Pedoman Umum Format Penulisan Tesis Program Pasca Sarjana Universitas. 